ISSN.2621-9832

JURNAL MathEdu (MathematicEducationJournal) http://journal.ipts.ac.id/index.php/MathEdu Vol. 4 . No. 3 November 2021

\title{
UPAYA MENINGKATKAN HIGHER ORDER THINKING SKILL (HOTS) SISWA MENGGUNAKAN METODE INQUIRY
}

\author{
Oleh: \\ Trinanda Anugrah Tambun', Wirna Arifitriana ${ }^{2}$, Erwina Azizah Hasibuan² \\ ${ }^{1}$ Mahasiswa FKIP, Pendidikan Matematika, Universitas Graha Nusantara \\ 2,3 Dosen FKIP, Pendidikan Matematika, Universitas Graha Nusantara \\ e.mail : wirnaariv3ana@gmail.com
}

\begin{abstract}
ABSTRAK
Tujuan Penelitian ini antara lain: pertama: Untuk mengetahui peningkatan kadar HOTS siswa dengan menggunakan metode Inquiry pada pokok bahasan Operasi bilangan bulat. Kedua : Untuk mengetahui peningkatan hasil belajar siswa dengan menggunakan metode Inquiry pada pokok bahasan Operasi bilangan bulat. Ketiga : Untuk mengetahui peningkatan kemampuan guru mengelola pembelajaran dengan menggunakan metode Inquiry pada pokok bahasan Operasi bilangan bulat. Jenis penelitian ini adalah Penelitian Tindakan Kelas (PTK). Yang terdiri dari 2 siklus. Subjek penelitian ini adalah kelas V SDN No. 200205 Padangsidimpuan Selatan yang berjumlah 20 orang siswa. Objek penelitian ini adalah penerapan model pembelajaran Inquiry, yang bertujuan untuk meningkatkan kemampuan pemecahan masalah matematika siswa. Hasil penelitian menunjukkan bahwa kemampuan hasil belajar siswa dalam pembelajaran matematika melalui metode Inquiry dengan persentase hasil tes belajar siswa matematika yaitu 40\% dengan kategori "Cukup" pada siklus I menjadi 85\% dengan kategori "Baik" pada siklus II. Sedangkan untuk hasil observasi kemampuan guru pada siklus I diperoleh nilai 79\% dengan kategori "Cukup Baik” menjadi 86\% dengan kategori "Baik” pada siklus II.
\end{abstract}

Kata Kunci : HOTS, Inquiry, Bilangan bulat

\begin{abstract}
The objectives of this study include: first: To determine the increase in students' HOTS levels using the Inquiry method on the subject of integer operations. Second: To find out the increase in student learning outcomes by using the Inquiry method on the subject of integer operations. Third: To find out the increase in the ability of teachers to manage learning by using the Inquiry method on the subject of integer operations. This type of research is Classroom Action Research (CAR). Which consists of 2 cycles. The subject of this research is class V SDN No. 200205 South Padangsidimpuan, totaling 20 students. The object of this research is the application of the Inquiry learning model, which aims to improve students' mathematical problem solving abilities. The results showed that the ability of student learning outcomes in learning mathematics through the Inquiry method with the percentage of student learning test results in mathematics, namely $40 \%$ with the "Enough" category in the first cycle to $85 \%$ with the "Good" category in the second cycle. Meanwhile, the results of the observation of the teacher's ability in the first cycle obtained a score of 79\% in the "Good Enough" category to $86 \%$ with the "Good" category in the second cycle.
\end{abstract}

Keywords: HOTS, Inquiry, Integer

\section{PENDAHULUAN}

Pendidikan merupakan suatu komponen penting dalam mentransformasi ilmu pengetahuan, keahlian dan nilai-nilai akhlak dalam pembentukan jati diri bangsa. Dengan adanya pendidikan, manusia dapat memaksimalkan kemampuan potensi dirinya baik sebagai pribadi maupun warga masyarakat. Hal ini sesuai dengan tujuan pendidikan yang dipaparkan dalam UU nomor 20 tun 2003 pasal 1 tentang pendidikan, yaitu Pendidikan adalah usaha sadar dan terencana untuk mewujudkan suasana belajar dan proses pembelajaran agar peserta didik secara aktif mengembangkan potensi dirinya untuk memiliki kekuatan spiritual keagamaan, pengendalian diri, kepribadian, kecerdasan, akhlak mulia, serta keterampilan yang diperlukan dirinya, masyarakat, bangsa dan negara, juga pada pasal 19 tentang kurikulum, yaitu Kurikulum adalah seperangkat rencana dan pengaturan mengenai tujuan, isi, dan bahan pelajaran serta cara yang digunakan sebagai pedoman penyelenggaraan kegiatan pembelajaran untuk mencapai tujuan pendidikan tertentu.

Tujuan pendidikan adalah perubahan perilaku yang diinginkan terjadi setelah siswa belajar. Tujuan pendidikan dapat dijabarkan melalui dari tujuan nasional, institusional, kurikuler sampai intruksional (Arikunto, 1995: 130). Untuk dapat mencapai tujuan pendidikan nasional maka tujuan pembangunan nasional dalam sektor 
ISSN.2621-9832

JURNAL MathEdu (MathematicEducationJournal)

http://journal.ipts.ac.id/index.php/MathEdu

Vol. 4 . No. 3 November 2021

pendidikan diturunkan kedalam beberapa tujuan pendidikan mulai tujuan nasional hingga tujuan tingkat pembelajran. Salah satu upaya dapat dilakukan yaitu dengan melakukan inovasi pembelajaran.

Pada saat ini, kurikulum yang tengah dikembnagkan adalah Kurikulum 2013 yang merupakan langkah lanjutan Pengembangan Kurikulum Berbasis Kompetensi yang telah dirintis pada tahun 2004 dan KTSP 2006 yang mencakup kompetensi sikap, pengetahuan, dan keterampilan secara terpadu. Di dalam dunia pendidikan, menganalisis, mengevaluasi dan mengaplikasikan ini termasuk ke dalam keterampilan berpikir tingkat tinggi. Keterampilan berpikir tingkat tinggi atau dalam bahasa Inggris higherorder thinking skills (HOTS) ialah hal yang penting dan sekarang menjadi perhatian dalam bidang pendidikan.

Pentingnya HOTS bagi siswa mengakibatkan HOTS diajarkan dan dilatihkan dalam setiap pembelajaran di sekolah, termasuk dalam pembelajaran matematika. Sebenarnya, Undang-Undang Nomor 20 Tahun 2003 tentang Sistem Pendidikan Nasional Pasal 3 yang berbunyi "Pendidikan nasional berfungsi mengembangkan dan membentuk watak serta peradaban bangsa, bertujuan untuk berkembangnya potensi peserta didik agar menjadi manusia yang beriman dan bertakwa kepada Tuhan Yang Maha Esa, berakhlak mulia, sehat, berilmu, cakap, kreatif, mandiri, dan menjadi warga negara yang demokratis serta bertanggung jawab" secara tersirat menginginkan agar HOTS peserta didik dikembangkan dan salah satunya melalui proses pembelajaran (Riadi dan Retnawati, 2014).

HOTS sangat diperlukan oleh siswa karena permasalahan yang akan mereka hadapi dalam kehidupan sesungguhnya bersifat kompleks, tidak terstruktur, rumit, dan memerlukan keterampilan berpikir yang bukan sekedar menerapkan apa yang sudah dipelajari (Riadi dan Retnawati, 2014). Sedangkan dalam pembelajaran matematika sendiri, HOTS merupakan salah satu keterampilan yang penting untuk dikembangkan (Apino dan Retnawati, 2017) dan sangat diperlukan karena mata pelajaran matematika akan membekali siswa kemampuan berpikir logis, analitis, sistematis, kritis, kreatif, serta kemampuan bekerja sama (Riadi dan Retnawati, 2014).

Namun pada kenyataannya dilapangan ketika peneliti melakukan observasi di SDN 200205 Padangsidimpuan Selatan menemukan beberapa masalah dalam mempelajari matematika. Siswa kebanyakan tidak bisa mengerjakan soal-soal yang diberikan kedalam model matematika. Dengan adanya rasa percaya diri, siswa akan lebih aktif dan berani menyelesaikan persoalan dengan kemampuan yang dimilikinya.

Fakta yang ada diperkuat dengan wawancara yang dilakukan penulis kepada guru bidang studi matematika ibu Masnora, S.Pd di SDN 200205 Padangsidimpuan Selatan yang mengungkapkan bahwa percaya diri siswa kelas $\mathrm{V}$ pada materi Operasi bilangan bulat cenderung rendah. Siswa masih banyak mengalami kendala dalam menyelesaikan soal tersebut untuk mencapai KKM yang ditentukan yaitu"75"

Salah satu metode yang berorientasi kepada kegiatan yang dapat meningkatkan kemampuan belajar siswa dalam kegiatan belajar adalah Metode Inquiry. Gulo (Trianto, 2011:68) menyatakan bahwa “ Inquiry tidak hanya mengembangkan kemampuan intelektual tetapi seluruh potensi yang ada, termasuk pengembangan emosional dan keterampilan Inquiry merupakan suatu proses yang bermula dari merumuskan masalah, merumuskan hipotesis, mengumpulkan data, menganalisis data, dan membuat kesimpulan. Berdasarkan latar belakang diatas akan disampaikan hasil dari Upaya Meningkatkan Higher Order Thinking Skill (HOTS) Siswa Menggunakan Metode Inquiry Pada Materi Bilangan Bulat Bagi Siswa Kelas V SDN 200205 Padangsidimpuan Selatan Tahun Ajaran 2020/2021.

\section{METODE}

Jenis penelitian ini adalah penelitian tindakan kelas ( Classroom Action 1 Research). Arikunto (2012: 58) menyatakan bahwa Penelitian Tindakan Kelas (PTK) adalah penelitian tindakan (Action Reseach) yang dilakukan dengan tujuan memperbaiki mutu praktik pembelajaran dikelas. Suhardjono (2007: 58) mengatakan bahwa penelitian tindakan kelas adalah penelitian tindakan yang dilakukan. Sedangkan dikelas dengan tujuan untuk memperbaiki/meningkatkan mutu praktik pembelajaran.

Tes yang diberikan kepada siswa dalam penelitian ini berupa tes kemampuan berfikir dan Tes hasil belajar siswa. Dari tes tersebut akan dilihat dimana letak kesulitan siswa dan tingkat kemampuan Berfikir Kritsi siswa supaya bisa disusun perencanan tindakan yang akan dilaksanakan dikelas tersebut. Dari tes yang dilakukan ini juga dapat dilihat apakah dengan metode Inquiry dapat meningkatkan hasil belajar siswa dan meningkatkan kepepercayaan diri siswa.

Subjek dalam penelitian ini adalah siswa kelas V SDN 200205 Padangsidimpuan Selatan Tahun Ajaran 2020/2021, sedangkan objek penelitian ini adalah Upaya Meningkatkan Higher Order Thinking Skill (HOTS) Siswa Menggunakan Metode Inquiry Pada Materi Bilangan Bulat Bagi Siswa Kelas V SDN 200205 Padangsidimpuan Selatan Tahun Ajaran 2020/2021. Metode Inquiry adalah metode pembelajaran yang menekankan pada Proses pembelajaran yang membuat siswa Berfikir tingkat tinggi dan analitis. Menurut Komalasari (2010: 73) Inquiry merupakan metode pembelajaran yang berupaya menanamkan dasar-dasr pemikiran ilmiah pada diri siswa, sehingga dalam proses pembelajaran ini siswa lebih banyak belajar sendiri, mengembangkan kreatifitas dalam memahami konsep dan memecahkan masalah. 
ISSN.2621-9832

JURNAL MathEdu (MathematicEducationJournal) http://journal.ipts.ac.id/index.php/MathEdu Vol. 4 . No. 3 November 2021

Penelitian ini dilaksanakan di SDN 200205 Padangsidimpuan Selatan pada kelas V tahun ajaran 2020/2021. Alasan peneliti memilih lokasi penelitian ini adalah karena belum ada penelitian yang sejenis disekolah tersebut. Waktu penelitian dilaksanakan pada semester ganjil Tahun Pelajaran 2020/2021.

Penerapan metode Inquiry dalam proses belajar mengajar menuntut keaktipan siswa dalam belajar individu, maupun kelompok.

\section{HASIL DAN PEMBAHASAN}

Hasil penelitian tindakan siklus I diuraiakan dalam beberapa tahapan. Adapun tahapan yang dilakukan dalam proses Penelitian Tindakan Kelas (PTK) di kelas V SDN 200205 Padangsidimpuan Selatan dilaksanakan yaitu perencanaan tindakan, pelaksanaan tindakan, observasi, dan refleksi. Hasil penelitian siklus I diuraikan sebagai berikut:

Siklus I merupakan pembelajaran dengan pokok bahasan Operasi Bilangan Bulat. Metode Inquiry mulai diperkenalkan pada siswa dalam pembelajaran untuk melihat hasil peningkatan hasil belajar matematika siswa di SDN 200205 Padangsidimpuan Selatan. Diakhiri pembelajaran Siklus I berlangsung, dilaksanakan tes Kemampuan Berfikir tingkat tinggi siswa matematika, maka hasil yang didapatkan dari tes tersebut dapat dilihat pada tabel berikut ini:

Tabel 1 Pengklasifikasian Nilai Hasil Tes Siklus I

\begin{tabular}{ccccc}
\hline No & $\begin{array}{c}\text { Tingkat } \\
\text { Kemampuan }\end{array}$ & Jumlah Siswa & Persentase & Klasilifikasi Nilai \\
\hline 1 & $90-100$ & 5 & $25 \%$ & Sangat Baik \\
\hline 2 & $80-89$ & 3 & $15 \%$ & Baik \\
\hline 3 & $65-79$ & 0 & $0 \%$ & Cukup \\
\hline 4 & $55-64$ & 5 & $25 \%$ & Kurang \\
\hline 5 & $0-54$ & 7 & $35 \%$ & Sangat Kurang \\
\hline
\end{tabular}

Dari tabel 1 di atas, dari 20 siswa yang mengikuti tes diperoleh 5 orang atau $25 \%$ siswa dengan kategori "Sangat Baik", 3 orang siswa atau 15\% dengan kategori "Baik", 5 orang siswa atau 25\% dengan kategori "Kurang”, dan 7 orang siswa atau 35\% dengan kategori " Sangat Kurang”. Namun peningkatan ini belum mencapai kriteria ketuntasan yang diharapkan, karena jumlah siswa yang memperoleh kategori minimal cukup sebanyak 8 orang siswa atau sebesar $40 \%$ dari 20 siswa yang mengikuti tes, sehingga belum mencapain target yang telah di tentukan yaoti sebesar $80 \%$ maka di adakan refleksi pada siklus berikutnya yaitu siklus II. Siklus kedua dalam penelitian ini terdiri dari perencanaan, pelaksanaan, pengamatan dan refleksi.

Tabel 2 Pengklasifikasian Nilai Hasil Tes Siklus I

\begin{tabular}{ccccc}
\hline No & $\begin{array}{c}\text { Tingkat } \\
\text { Kemampuan }\end{array}$ & Jumlah Siswa & Persentase & Klasilifikasi Nilai \\
\hline 1 & $90-100$ & 3 & $15 \%$ & Sangat Baik \\
\hline 2 & $80-89$ & 14 & $70 \%$ & Baik \\
\hline 3 & $65-79$ & 0 & $0 \%$ & Cukup \\
\hline 4 & $55-64$ & 0 & $0 \%$ & Sungang Kurang \\
\hline 5 & $0-54$ & 3 & $15 \%$ & \\
\hline
\end{tabular}

Dari tabel 2 di atas, dari 20 siswa yang mengikuti tes diperoleh 3 orang atau 25\% siswa dengan kategori "Sangat Baik", 14 orang siswa atau 70\% dengan kategori " Baik dan 3 orang siswa atau 15\% dengan kategori "Sangat Kurang”. Dkarna sudah mencapai kategori yang diharapkan yaitu dengan kategori minimal "Baik" maka penelitian ini diberhentikan.

Hasil Observasi Kemampuan Guru Mengelola Pembelajaran

Pengamatan atau observasi juga dilakukan terhadap kemampuan guru mengelola pembelajaran. Observer memiliki peran untukmengamati dan memotret semua aktivitas guru yang terjadi di kelas ketika tindakan di lakukan. Hasil observasi kemampuan guru mengelola pembelajaran melalui metode Inquiry di sajikan dalam tabel berikut ini: 
ISSN.2621-9832

JURNAL MathEdu (MathematicEducationJournal) http://journal.ipts.ac.id/index.php/MathEdu Vol. 4 . No. 3 November 2021

Tabel 3. Kemampuan Guru Mengelolah Pembelajaran Siklus I

\begin{tabular}{|c|c|c|c|c|}
\hline NO. & Aspek yang Dinilai & $\begin{array}{l}\text { Pertemuan } \\
\text { I }\end{array}$ & $\begin{array}{l}\text { Pertemuan } \\
\text { II }\end{array}$ & $\begin{array}{l}\text { Rata- } \\
\text { rata }\end{array}$ \\
\hline & Pendahuluan & & & \\
\hline 1 & Kemampuan menyampaikan kembali materi secara singkat & 4 & 5 & 4,5 \\
\hline 2 & Kemampuan menyampaikan tujuan pembelajaran & 4 & 5 & 4,5 \\
\hline 3 & Kemampuan menyampaikan langkah-langkah pembelajaran & 4 & 5 & 4.5 \\
\hline 4 & $\begin{array}{l}\text { Kemampuan mengontrol dan membimbing siswa dalam } \\
\text { membagi kelompok belajar }\end{array}$ & 4 & 4 & 4 \\
\hline \multirow[t]{2}{*}{5} & $\begin{array}{l}\text { Kemampuan memotivasi dan menumbuhkan minat siswa } \\
\text { dengan menjelaskan materi }\end{array}$ & 5 & 5 & 5 \\
\hline & Inti & & & \\
\hline 6 & $\begin{array}{l}\text { Kemampuan menyajikan materi yang berkaitan dengan } \\
\text { Bilangan Bulat }\end{array}$ & 4 & 5 & 4,5 \\
\hline 7 & $\begin{array}{l}\text { Kemampuan guru dalam membimbing siswa dalam } \\
\text { mengerjakan LKS/masalah }\end{array}$ & 4 & 4 & 4 \\
\hline 8 & $\begin{array}{l}\text { Kemampuan guru meminta siswa untuk mengemukakan ide } \\
\text { kelompoknya sendiri dalam menyelesaikan masalah }\end{array}$ & 4 & 4 & 4 \\
\hline 9 & $\begin{array}{l}\text { Kemampuan mendorong siswa untuk mengumpulkan } \\
\text { informasi yang sesuai dan menemukan penjelasan dalam } \\
\text { Berpikir Kritis yang diberikan }\end{array}$ & 3 & 3 & 3 \\
\hline 10 & $\begin{array}{l}\text { Kemampuan mendorong siswa untuk berdiskusi antar teman } \\
\text { dalam kelompoknya masing-masing }\end{array}$ & 4 & 4 & 4 \\
\hline 11 & $\begin{array}{l}\text { Kemampuan mendorong siswa menyajikan hasil Berpikir } \\
\text { Kritis dan membimbing apabila menemui kesulitan }\end{array}$ & 4 & 4 & 4 \\
\hline 12 & $\begin{array}{l}\text { Kemampuan mendorong siswa untuk mau bertanya dan } \\
\text { menjawab pertanyaan }\end{array}$ & 5 & 5 & 5 \\
\hline \multirow[t]{2}{*}{13} & $\begin{array}{l}\text { Kemampuan memberikan penghargaan kepada siswa yang } \\
\text { aktif dan berprestasi serta memberi semangat kepada siswa } \\
\text { yang kurang aktif }\end{array}$ & 4 & 5 & 4,5 \\
\hline & Penutup & & & \\
\hline 14 & $\begin{array}{l}\text { Kemampuan dalam menyimpulkan materi pembelajaran dan } \\
\text { menegaskan kembali hal-hal penting yang berkaitan dengan } \\
\text { materi yang telah diajarkan }\end{array}$ & 4 & 4 & 4 \\
\hline 15 & $\begin{array}{l}\text { Kemampuan menyampaikan materi untuk pertemuan } \\
\text { berikutnya }\end{array}$ & 4 & 4 & 4 \\
\hline 16 & Kemampuan guru dalam mengelolah waktu suasana kelas & 3 & 4 & 4 \\
\hline 17 & Antusias siswa & 5 & 5 & 5 \\
\hline \multirow[t]{4}{*}{18} & Adanya interaksi aktif antara guru dan siswa & 4 & 4 & 4 \\
\hline & Skor Total & & & 71,5 \\
\hline & Skor Maksimum & & & 90 \\
\hline & \multicolumn{4}{|c|}{ Persentase Aktivitas Guru $\frac{71,5}{90} \times 100 \%=79,44 \%$} \\
\hline
\end{tabular}

Berdasarkan tabel diatas, menunjukkan persentase skor aktivitas guru yang diperoleh dalam mengelolah pembelajaran termasuk dalam kategori "Cukup baik". Tetapi masih ada beberapa aspek yang berada pada kategori kurang, yaitu: 1) kemampuan untuk mendorong siswa untuk mengumpulkan informasi yang sesuai dan menemukan penjelasan dalam Berpikir Kritis. 2) kemampuan guru dalam mengelolah waktu. Ini akan menjadi bahan perbaikan dalam pertemuan selanjutnya siklus II. 
ISSN.2621-9832

JURNAL MathEdu (MathematicEducationJournal) http://journal.ipts.ac.id/index.php/MathEdu Vol. 4 . No. 3 November 2021

Hasil observasi kemampuan guru mengelola pembelajaran pada siklus II di sajikan dalam tabel berikut:

Tabel 4 Kemampuan Guru Mengelola Pembelajaran

\begin{tabular}{|c|c|c|c|c|}
\hline NO. & Aspek yang Dinilai & $\begin{array}{l}\text { Pertemuan } \\
\text { III }\end{array}$ & $\begin{array}{l}\text { Pertemuan } \\
\text { IV }\end{array}$ & $\begin{array}{c}\text { Rata- } \\
\text { rata }\end{array}$ \\
\hline & Pendahuluan & & & \\
\hline 1. & $\begin{array}{l}\text { Kemampuan menyampaikan kembali materi secara } \\
\text { singkat }\end{array}$ & 5 & 5 & 5 \\
\hline 2. & Kemampuan menyampaikan tujuan pembelajaran & 4 & 5 & 4,5 \\
\hline 3. & $\begin{array}{lll}\begin{array}{l}\text { Kemampuan } \\
\text { pembelajaran }\end{array} & \text { menyampaikan langkah-langkah }\end{array}$ & 5 & 5 & 5 \\
\hline 4. & $\begin{array}{l}\text { Kemampuan mengontrol dan membimbing siswa } \\
\text { dalam membagi kelompok belajar }\end{array}$ & 4 & 5 & 4 \\
\hline \multirow[t]{2}{*}{5.} & $\begin{array}{l}\text { Kemampuan memotivasi dan menumbuhkan minat } \\
\text { siswa dengan menjelaskan materi }\end{array}$ & 5 & 5 & 5 \\
\hline & Inti & & & \\
\hline 6. & $\begin{array}{l}\text { Kemampuan menyajikan materi yang berkaitan } \\
\text { dengan SPLDV }\end{array}$ & 4 & 5 & 4,5 \\
\hline 7. & $\begin{array}{l}\text { Kemampuan guru dalam membimbing siswa dalam } \\
\text { mengerjakan LKS/masalah }\end{array}$ & 4 & 5 & 4 \\
\hline 8. & $\begin{array}{lccc}\text { Kemampuan guru meminta } & \text { siswa untuk } \\
\text { mengemukakan ide kelompoknya } & \text { sendiri } & \text { dalam } \\
\text { menyelesaikan masalah } & & & \\
\end{array}$ & 4 & 4 & 4 \\
\hline 9. & $\begin{array}{l}\text { Kemampuan mendorong siswa untuk mengumpulkan } \\
\text { informasi yang sesuai dan menemukan penjelasan } \\
\text { dalam Berpikir Kritis yang diberikan }\end{array}$ & 4 & 4 & 4 \\
\hline 10. & $\begin{array}{l}\text { Kemampuan mendorong siswa untuk berdiskusi antar } \\
\text { teman dalam kelompoknya masing-masing }\end{array}$ & 4 & 4 & 4 \\
\hline 11. & $\begin{array}{l}\text { Kemampuan mendorong siswa menyajikan hasil } \\
\text { Berpikir Kritis dan membimbing apabila menemui } \\
\text { kesulitan }\end{array}$ & 4 & 4 & 4 \\
\hline 12. & $\begin{array}{l}\text { Kemampuan mendorong siswa untuk mau bertanya } \\
\text { dan menjawab pertanyaan }\end{array}$ & 5 & 5 & 5 \\
\hline \multirow[t]{2}{*}{13.} & $\begin{array}{l}\text { Kemampuan memberikan penghargaan kepada siswa } \\
\text { yang aktif dan berprestasi serta memberi semangat } \\
\text { kepada siswa yang kurang aktif }\end{array}$ & 4 & 5 & 4,5 \\
\hline & Penutup & & & \\
\hline 14. & $\begin{array}{l}\text { Kemampuan dalam menyimpulkan materi } \\
\text { pembelajaran dan menegaskan kembali hal-hal } \\
\text { penting yang berkaitan dengan materi yang telah } \\
\text { diajarkan }\end{array}$ & 4 & 4 & 4 \\
\hline 15. & $\begin{array}{l}\text { Kemampuan menyampaikan materi untuk pertemuan } \\
\text { berikutnya }\end{array}$ & 4 & 4 & 4 \\
\hline 16. & $\begin{array}{l}\text { Kemampuan guru dalam mengelolah waktu suasana } \\
\text { kelas }\end{array}$ & 3 & 4 & 3,5 \\
\hline 17. & Antusias siswa & 5 & 5 & 5 \\
\hline \multirow[t]{4}{*}{18.} & Adanya interaksi aktif antara guru dan siswa & 4 & 4 & 4 \\
\hline & Skor Total & & & 78 \\
\hline & Skor Maksimum & & & 90 \\
\hline & \multicolumn{4}{|l|}{ Persentase Aktivitas Guru $\frac{78}{90} \times 100 \%=86,7 \%$} \\
\hline
\end{tabular}

kemampuan guru dalam mengelola pembelajaran mencapai 86,7\% dengan kategori “ Sangat Baik"atau sudah mencapai minimal $80 \%$. Penelitian ini dihentikan pada siklus ini karena hasil kemampuan guru dalam mengelola pembelajaran mencapai kategori “Sangat Baik" atau sudah mencapaiminimal 80\%. Hasil ini di dapat sesuai dengan hasil yang diharapkan maka siklus ini di hentikan. 
ISSN.2621-9832

JURNAL MathEdu (MathematicEducationJournal)

http://journal.ipts.ac.id/index.php/MathEdu

Vol. 4 . No. 3 November 2021

Ditinjau dari tingkat Kemampuan Berfikir tingkat tinggi siswa matematika, pada awal penelitian dan catatan penelitian selama melakukan penelitian. Diawali penelitian di berikan tindakan pada siklus I sebanyak 2 kali pertemuan, siswa diberikan tes, diperoleh sebanyak 5 orang siswa dengan persentase $40 \%$ dari 20 orang siswa mencapai nilai minimal "Cukup".sedangkan 15 orang siswa belum mencapai tingkat yang diharapkan.Selanjutnya tes Kemampuan Berfikir tingkat tinggi siswa matematika pada siklus II mengalami peningkatan menjadi $100 \%$. Berdasarkan hasil observasi pada siklus I, siswa dan guru sudah melakukan pembelajaran dengan menggunakan metode Inquiry.

Hal-hal yang harus diperbaiki pada tindakan siklus II adalah guru dan keikutsertaan siswa dalam kelompok.Guru juga harus mampu menciptakan suasana belajar yang kondusif dan mengelola waktu seefisien mungkin agar tahapan dalam skenario pembelajaran dapat terlaksana.

Pada tindakan siklus II, strategi pembelajaran tetap dilaksanakan. Berdasarkan hasil observasi pada tindakan siklus II, kegiatan guru dalam melaksanakan proses pembelajaran sudah meningkat, dimana kekurangan pada siklus I sudah diperbaiki. Setelah selesai pelaksanaan siklus II, nilai tes Kemampuan Berfikir tingkat tinggi siswa matematika meningkat dari siklus I yaitu yang berada pada kategori "Cukup Baik"meningkat pada siklus II dengan kategori "Baik".

\section{Peningkatan Kemampuan Guru Dalam Mengelola Pembelajaran}

Dari hasil observasipada siklus I guru telah melakukan kegiatan pembelajaran yang sesuai dengan Metode Inquiry. Namaun masih terdapat kekurangan, dimana pada saat pembelajaran guru belum terlaksanakannya semua komponen dalam skenario pembelajaran. Bila ditinjau dari segi aktivitas selama tindakan di berikan pada siklus I diperoleh kemampuan guru dalam mengelola pembelajaran sebesar 79\% dengan kategori "Cukup Baik", sudah memenuhi kriteria yang di tentukan. Walaupun sudah memenuhi namun terus berlanjut ke siklus II agar mendapatkan nilai yang lebih baik lagi. Kemudian selama tindakan pada siklus II di peroleh kemampuan guru dalam mengelola pembelajaran sebesar 86,7\% dengan kategori Baik". Melihat kekurangan yang masih ada pada kemampuan guru dalam pembelajaran pada siklus I belum memenuhi tolak ukur keberhasilan ditentukan maka penelitian dilanjutkan pada siklus II. Hal-hal yang harus diperbaiki pada tindakan siklus II adalah penguasaan guru terhadap langkah-langkah metode inquiry.

\section{Simpulan}

Berdasarkan tujuan penelitian, hasil penelitian dan pembahasan, maka penelitian yang dilaksanakan di kelas V SDN 200205 Padangsidimpuan Selatan Tahun Pelajaran 2020/2021 dapat di simpulkan sebagai berikut: Kemampuan HOTS siswa dengan menggunakan metode Inquiry pada pokok bahasan Operasi bilangan bulat di kelas V SDN 200205 Padangsidimpuan Selatan tahun pelajaran 2020/2021 meningkat. Hal ini dapat ditunjukkan dengan persentase hasil tes belajar siswa matematika yaitu 40\% dengan kategori "Cukup" pada siklus I menjadi 85\% dengan kategori "Baik" pada siklus II. Kemampuan guru dalam mengelola pembelajaran dengan menggunakan metode Inquiry pada pokok bahasan Operasi bilangan bulat di kelas V SDN 200205 Padangsidimpuan Selatan tahun pelajaran 2020/2021 meningkat. Hal ini dilihat dari hasil observasi kemampuan guru dalam mengelola pembelajaran pada siklus I memperoleh persentase $79,44 \%$ dengan kategori "Cukup Baik" menjadi 86,7\% dengan kategori "Baik" pada siklus II.

\section{Saran}

Telah terbukti bahwa metode Inquiry dapat meningkatkan pembelajaran matematika pada siswa Kelas V SDN 200205 Padangsidimpuan pada materi Operasi Bilangan Bulat tahun pelajaran 2020/2021. maka disarankan halhal sebagai berikut:

1. Dalam penerapan metode Inquiry hendaknya memperhatikan keaktifan siswa dan hasil belajar siswa dalam proses belajar mengajar agar tercipta suasana belajar yang aktif, kondusif dan nyaman.

2. Dalam kegiatan belajar mengajar guru diharapkan menjadikan metode Inquiry sebagai salah satu alternative dalam pembelajaran matematika.

3. Karena kegiatan ini sangat bermanfaat khususnya bagi guru dan siswa diharapkan kegiatan ini dapat dilakukan secara berkesinambungan dalam pembelajaran matematika.

4. Kepada peneliti selanjutnya, semoga penelitian ini dapat bermanfaat bagi peneliti selanjutnya sebagai bahan referensi untuk pengembangan penelitian yang sejenis agar jauh lebih baik dalam menyelesaikan masalah-masalah pembelajaran matematika.

\section{Daftar Pustaka}

Agus Suprijono. (2012). Cooperative Learning Teori Dan Aplikasi PAIKEM. Yogyakarta: Pustaka Pelajar. Arikunto, Suharsimi. (2016). Prosedur Penelitian, Suatu Pendekatan Praktik. Jakarta: Rineka Cipta. 
Armai Arif. (2002). Pengantar Ilmu Dan Metodeologi Pendidikan Islam. Jakarta: Ciputat Pers.

Depdiknas. (2003). Undang-Undang Nomor 20 Tahun 2003 Tentang Sistem Pendidikan Nasional. Jakarta: Depdiknas.

Departemen Pendidikan Nasional. (2003). Kamus Besar Bahasa Indonesia. Jakarta: Balai Pustaka.

Ghufron, M. Nur dan Rini Risnawati S. (2011). Teori-Teori Psikologi. Yogyakarta: Ar-Ruzz Media.

Goel, M. Dan P. Aggarwal. (2012). A Comparative Study Of Self Confidence of Singel child and cild with sibling . USA: International Journal Of Research In Social Sciences.

Hamdani. (2011). Strategi Belajar Mengajar. Bandung: CV Pustaka Setia.

Huda, Miftahul. (2017). Model-Model Pengajaran Dan Pembelajaran. Yogyakarta: Pustaka Pelajar.

Hanafia, Nanang dan Suhana, Cucu. (2009). Konsep Strategi Pembelajaran. Bandung: PT Refika Aditama. Mathematicc Education.

Karunia. Eka L. Dan Muhammad Ridwan Y. 2015. Penelitian Pendidikan Matematika.Bandung: Prakata. Komalasari. Kokom. (2010). Pembelajaran Kontekstua. Bandung: PT Refika Aditama.

Muchtar. A. Karim, et. al. (1996). Pendidikan Matematika I. Jakarta: Depdikbud.

Mutijah, dan Ifada Novikasari. (2009). Bilangan Dan Aritmatika. Purwokerto: STAIN Purwokerto Press.

Nana Sujdana. (2005). Penilaian Hasil Proses Belajar Mengajar. Bandung: PT Remaja Rosdakarya.

Ngalimun. (2014). Strategi dan Model Pembelajaran. Yogyakarta: Aswaja Presindo

Purwanto. (2017). Evaluasi Hasil Belajar. Yogyakarta: Pustaka Pelajar.

Purwanto. (2011). Evaluasi Hasil Belajar.Yogyakarta: Pustaka Pelajar.

Srini M. Iskandar. (1996/1997). Pendidikan Ilmu Pengetahuan Alam. Defdikbud Dikti.

Suherman, Erman dkk. 2003. Strategi Pembelajaran Matematika Kontemporer. Bandung:PT Remaja Rosdakarya.

Trianto. (2009). Pendesain Model Pembelajaran Inovatif Progresif.

W. Gulo. (2002). Strategi Belajar Mengajar. Jakarta: Gramedia Widiarsana Indonesia. 